\section{Peritonitis from facultative anaerobic gram-negative bacilli likely due to translocation of bacteria from gut in a patient undergoing peritoneal dialysis}

\author{
Sreedhar Adapa, ${ }^{1}$ Srikanth Naramala, ${ }^{2}$ \\ Harmandeep Singh Tiwana, ${ }^{3}$ \\ Niraj Patel, ${ }^{4}$ Raman Verma, ${ }^{4}$ \\ Narayana Murty Koduri, ${ }^{5}$ Venu Madhav \\ Konala $^{6}$ \\ ${ }^{1}$ The Nephrology group, Fresno, CA; \\ ${ }^{2}$ Department of Rheumatology, \\ Adventist Medical Center, Hanford, CA; \\ ${ }^{3}$ Department of Internal Medicine, \\ Adventist Medical Center, Hanford, CA; \\ ${ }^{4}$ Department of Internal Medicine, \\ Kaweah Delta Medical Center, Visalia, \\ CA; 'Department of Psychiatry, Great \\ Plains Health, North Platte, NE; \\ ${ }^{6}$ Ashland Bellefonte Cancer Center, \\ Ashland, KY, USA
}

\begin{abstract}
The peritonitis caused by gram-negative organisms is a serious complication encountered in patients undergoing peritoneal dialysis, often causing high morbidity and mortality. There has been recognition of peritonitis caused by uncommon organisms because of improved microbiological detection techniques. The healthcare providers involved in the management of these patients should be very vigilant. We report a rare case of peritonitis caused by Citrobacter freundii. A 42-year-old male on peritoneal dialysis for five years presented with abdominal pain and cloudy effluent. The peritoneal fluid analysis was consistent with peritonitis, and peritoneal fluid culture grew Citrobacter freundii. The patient was treated with two courses of double antibiotic coverage with intraperitoneal ceftazidime and oral ciprofloxacin, which failed to resolve the infection and hence resulted in the removal the peritoneal dialysis catheter and dialysis modality change.
\end{abstract}

\section{Introduction}

Gram-negative organism peritonitis is a severe complication encountered in patients undergoing peritoneal dialysis, often causing high morbidity and mortality. The healthcare providers involved in the care of patients undergoing peritoneal dialysis should recognize that unusual organisms could cause peritonitis. We report the case of a 42-year-old male on peritoneal dialysis presenting with Citrobacter freundii peritonitis.

Citrobacter freundii (C. freundii) is a motile, facultative anaerobe, non-sporing gram-negative bacilli colonize in the gastrointestinal tract of humans and other animals. It is also found in water, soil, and food. ${ }^{1}$ Werkman and Gillen discovered genus Citrobacter in 1932 and the organism uses citrate a sole carbon source for the energy source and hence derives its name. ${ }^{2}$ C. freundii is hydrogen sulfide positive, indole negative, adonitol negative, and malonate negative in character. ${ }^{3}$ Peritonitis from gram-negative organisms frequently results in hospitalization, catheter loss, dialysis modality change, and mortality. These infections are hard to treat because of biofilm formation, which makes them less susceptible to antibiotics.

\section{Case Report}

A 42-year-old male on peritoneal dialysis presented with abdominal pain and cloudy effluent of one-day duration. The patient denied any fever and denied any in advent breach in the technique while making peritoneal dialysis connections. Moreover, the patient denied history of diarrhea or constipation. The patient has been on peritoneal dialysis for five years and had no prior history of peritonitis. Past medical history was signification for diabetes, hypertension, hyperlipidemia, hyperparathyroidism, end-stage renal disease on peritoneal dialysis. Home medications included metoprolol 100 milligrams (mg) twice a day, nifedipine $60 \mathrm{mg}$ extendedrelease daily, atorvastatin $80 \mathrm{mg}$ daily, sevelamer $2400 \mathrm{mg}$ three times a day with meals, calcitriol 0.5 micrograms (mcg) daily, gabapentin $100 \mathrm{mg}$ daily at bedtime, cinacalcet $30 \mathrm{mg}$ daily, insulin glargine 15 units daily, insulin sliding scale.

The vital signs on presentation were the temperature of 36.4 Celsius, pulse rate of 84 beats per minute, respiratory rate of 16 breath per minute, blood pressure of 158/95 $\mathrm{mm} \mathrm{Hg}$. Physical examination revealed abdominal tenderness with a peritoneal dialysis catheter in the right lower quadrant. There was no exit site drainage or redness along the tunnel and the rest of the physical examination was nonsignificant.

Laboratory analysis showed white blood count $10300 \mathrm{~mm} 3$, hemoglobin 11.2 $\mathrm{gm} / \mathrm{dl}$, platelet count $22300 \mathrm{~mm} 3$, sodium $138 \mathrm{mmol} / \mathrm{l}$, potassium $4.5 \mathrm{mmol} / \mathrm{l}$, bicarbonate $22 \mathrm{mmol} / \mathrm{l}$, blood urea nitrogen 58 $\mathrm{mg} / \mathrm{dl}$, creatinine $11.6 \mathrm{mg} / \mathrm{dl}$, albumin 3.3 $\mathrm{g} / \mathrm{dl}$. The peritoneal fluid effluent revealed peritoneal fluid white blood cells (WBC)
Correspondence: Sreedhar Adapa, The Nephrology Group, 568 East Herndon Avenue \#201, Fresno, CA 93720, USA.

Tel.: 5592286600 - Fax: 5592263709.

E-mail: sreedharadapa@gmail.com

Key words: Citrobacter freundii, peritonitis, SPICE organisms, peritoneal dialysis.

Contributions: All authors contributed equally to the text of the manuscript and the literature review. SA was responsible for the original diagnosis and treatment. Manuscript preparation and modification by VM.

Conflict of interest: The authors declare no potential conflict of interest.

Funding: None.

Availability of data and materials: PubMed database. The authors declare that data supporting the findings of the discussion are available within the article.

Ethics approval and consent to participate: Our institution does not require ethical approval for individual case reports.

Informed consent: Verbal informed consent from the patient has been obtained for their anonymized information to be published in this article.

Received for publication: 10 November 2019. Revision received: 5 March 2020.

Accepted for publication: 25 March 2020

This work is licensed under a Creative Commons Attribution-NonCommercial 4.0 International License (CC BY-NC 4.0).

C Copyright: the Author(s), 2020

Licensee PAGEPress, Italy

Infectious Disease Reports 2020; 12:8376

doi:10.4081/idr.2020.8376

1837 cells/ul with $85 \%$ predominant neutrophils. Peritoneal fluid gram stain revealed $>100 \mathrm{WBC}$, and no organisms were seen. The patient was started on empiric treatment for peritonitis with intraperitoneal vancomycin and ceftazidime. Later on, peritoneal fluid culture grew Citrobacter freundii in both aerobic and anaerobic bottles. The sensitivities of Citrobacter freundii were listed in Table 1 done by VITEK 2 method.

The patient was treated with double antibiotic coverage of intraperitoneal ceftazidime and oral ciprofloxacin for three weeks. The repeat peritoneal fluid cultures after finishing the antibiotic course yielded heavy growth of $C$. freundii again. The sensitivities of Citrobacter freundii are listed in Table 2 done. Another three weeks course 
of double antibiotic treatment (intraperitoneal ceftazidime and intravenous imipenem) was given, which failed to clear the organism. The symptoms resolved when peritoneal dialysis catheter was removed after failing two double antibiotic courses. Subsequently, he did not require a further course of antibiotics. The dialysis modality of the patient was then switched to hemodialysis and the patient continues to be hemodialysis dependent after two years of follow up.

\section{Discussion}

C. freundii belongs to the Enterobacteriaceae family, which accounts for more than $10 \%$ of cases of peritonitis. Serratia, Pseudomonas/Providencia, indole positive Proteus/Acinetobacter/Morganella, Citrobacter, Enterobacter, and Hafnia group of organisms (SPICE) are associated with peritonitis with high mortality, and morbidity. ${ }^{4}$ Citrobacter has low virulence and accounts for $4.8 \%$ of all Enterobacteriaceae peritonitis. ${ }^{5}$

C. freundii and C. koseri are the most pathogenic strains and cause seventy percent of human infections among the Citrobacter genus. Other medically important species in Citrobacter are $C$. amalonaticus, C. farmeri, C. braakii, C. werkmanii, and C. sedlakii. ${ }^{6}$ Citrobacter is the rare cause of peritonitis, and $C$. freundii is the common species involved, frequently leads to peritoneal dialysis catheter removal despite repeated courses of double antibiotic coverage. ${ }^{4}$ Dialysis patients are prone to have gastrointestinal colonization from gram-negative bacteria, particularly Citrobacter compared to the general population. Citrobacter peritonitis tends to be polymicrobial in $10-15 \%$ episodes com-

Table 1. Sensitivities of Citrobacter freundii, isolated in our patient with peritonitis.

\begin{tabular}{lcc} 
Antibiotic & Minimum inhibitory concentration & Sensitivity result \\
Cefazolin & $\geq 64 \mathrm{mcg} / \mathrm{ml}$ & Resistant \\
Cefepime & $\leq 1 \mathrm{mcg} / \mathrm{ml}$ & Sensitive \\
\hline Ceftazidime & $\leq 1 \mathrm{mcg} / \mathrm{ml}$ & Sensitive \\
Ceftriaxone & $\leq 1 \mathrm{mcg} / \mathrm{ml}$ & Sensitive \\
\hline Ciprofloxacin & $0.5 \mathrm{mcg} / \mathrm{ml}$ & Sensitive \\
Gentamicin & $\geq 16 \mathrm{mcg} / \mathrm{ml}$ & Resistant \\
\hline Imipenem & $2 \mathrm{mcg} / \mathrm{ml}$ & Sensitive \\
\hline
\end{tabular}

Table 2. Sensitivities of Citrobacter freundii during antibiotic treatment.

\begin{tabular}{lcc} 
Antibiotic & Ninimum inhibitory concentration & Sensitivity result \\
Cefazolin & $\geq 64 \mathrm{mcg} / \mathrm{ml}$ & Resistant \\
Cefepime & $\leq 1 \mathrm{mcg} / \mathrm{ml}$ & Sensitive \\
\hline Ceftazidime & $\leq 1 \mathrm{mcg} / \mathrm{ml}$ & Sensitive \\
Ceftriaxone & $\leq=1 \mathrm{mcg} / \mathrm{ml}$ & Sensitive \\
\hline Ciprofloxacin & $1 \mathrm{mcg} / \mathrm{ml}$ & Intermediate \\
Gentamicin & $\geq 16 \mathrm{mcg} / \mathrm{ml}$ & Resistant \\
\hline Imipenem & $1 \mathrm{mcg} / \mathrm{ml}$ & Sensitive \\
Levofloxacin & $4 \mathrm{mcg} / \mathrm{ml}$ & Intermediate \\
\hline Tobramycin & $8 \mathrm{mcg} / \mathrm{ml}$ & Resistant \\
Trimethoprim/Sulfamethoxazole & $\geq 320 \mathrm{mcg} / \mathrm{ml}$ & Resistant \\
\hline Piperacillin-tazobactam & $16 \mathrm{mcg} / \mathrm{ml}$ & Sensitive
\end{tabular}

Table 3. Summary all the cases listed as Citrobacter freundii peritonitis with patients on dialysis as per PubMed review of literature.

\begin{tabular}{|c|c|c|c|c|c|c|c|c|c|}
\hline Author & $\begin{array}{l}\text { Year } \\
\text { Gender }\end{array}$ & $\begin{array}{c}\text { Age/ } \\
\text { (months) }\end{array}$ & $\begin{array}{l}\text { Duration } \\
\text { Mode }\end{array}$ & $\begin{array}{l}\text { Dialysis } \\
\text { association }\end{array}$ & $\begin{array}{l}\text { Polymicrobial } \\
\text { culture }\end{array}$ & Dialysate & $\begin{array}{l}\text { Treatment } \\
\text { salvage }\end{array}$ & Catheter & Outcome \\
\hline Dervisoglu et al. . $^{8}$ & 2008 & $33 / \mathrm{F}$ & 96 & CAPD & No & Positive & $\begin{array}{l}\text { Intravenous } \\
\text { Meropenem } \\
\text { Intraperitoneal } \\
\text { Gentamicin }\end{array}$ & No & $\begin{array}{l}\text { Infection resolved } \\
\text { and patient was } \\
\text { switched to HD }\end{array}$ \\
\hline Farinha et al. ${ }^{9}$ & 2013 & $65 / \mathrm{M}$ & $\mathrm{NA}$ & NA & No & Positive & $\begin{array}{l}\text { IV Ceftazidime } \\
\text { IV piperacillin-tazobactam } \\
\text { IV Gentamicin }\end{array}$ & mo & $\begin{array}{l}\text { Patient died for } \\
\text { peritonitis before } \\
\text { completion of antibiotic } \\
\text { course and PD catheter } \\
\text { removal }\end{array}$ \\
\hline Kusaba et al $l^{10}$ & 2012 & $66 / \mathrm{M}$ & 12 & $\mathrm{NA}$ & $\begin{array}{c}\text { Yes } \\
\text { Enterococcus } \\
\text { Stenotrophomonas } \\
\text { Maltophilia }\end{array}$ & Positive & $\begin{array}{l}\text { Intraperitoneal } \\
\text { Ceftazidime } \\
\text { Intravenous } \\
\text { Vancomycin } \\
\text { Intravenous } \\
\text { Ciprofloxacin }\end{array}$ & No & $\begin{array}{l}\text { Infection resolved and } \\
\text { patient was switched to } \\
\text { HD }\end{array}$ \\
\hline Oh et al. ${ }^{11}$ & 2015 & $34 / F$ & 48 & CAPD & $\begin{array}{c}\text { Yes } \\
\text { Candida Tropicalis }\end{array}$ & Positive & $\begin{array}{l}\text { Intravenous } \\
\text { Gentamycin }\end{array}$ & No & $\begin{array}{l}\text { Infection resolved and } \\
\text { patient was switched to } \\
\text { HD }\end{array}$ \\
\hline Kataria et al. ${ }^{4}$ & 2015 & $76 / \mathrm{M}$ & 6 & CCPD & No & Positive & $\begin{array}{l}\text { Oral ciprofloxacin } \\
\text { and Intraperitoneal } \\
\text { Gentamicin }\end{array}$ & Yes & $\begin{array}{l}\text { Infection resolved with } \\
\text { antibiotics }\end{array}$ \\
\hline
\end{tabular}

CAPD, continuous ambulatory peritoneal dialysis; CCPD, continuous cyclic peritoneal dialysis; NIPD, nocturnal intermittent peritoneal dialysis; HD, hemodialysis; NA, not available. 
pared to $13-30 \%$ episodes in other infections. ${ }^{7}$ We summarized all the cases listed as C. freundii peritonitis on literature review from PubMed in Table 3. ${ }^{8-14}$

The patients who are at risk of developing infections from Citrobacter are elderly, immunocompromised, debilitated, and have multiple comorbidities. ${ }^{2}$ Invasive genitourinary procedures increase the risk of colonization and infection by this organism. ${ }^{2}$. The mode of transmission in peritonitis could be from microbial transmural migration from the gastrointestinal tract by their colonization accounting for $45 \%$ compared to $5-10 \%$ from other organisms. ${ }^{12,13}$ It is associated with constipation and/ or diarrhea in $46 \%$ of episodes in a case series. ${ }^{7}$ It is implicated in causing bacteremia, septicemia, superficial skin infections, brain abscess, meningitis, and urinary tract infections. ${ }^{2,4}$ Citrobacter is typically isolated using standard microbiological techniques using Mueller Hinton agar by the standard disc diffusion method recommended by the Clinical and Laboratory Standards Institute (CLSI). ${ }^{14}$ The genus Citrobacter can be identified by culture of the blood or body fluid and most of them ferment glucose with the production of gas and exclusively utilize citrate as a carbon source. Species differentiation is done by biochemical tests, DNA hybridization, and Vitek GNI+ card.

ISPD (International Society of peritoneal dialysis) 2016 guidelines recommends treating SPICE organisms for three weeks with double antibiotic coverage as per sensitivities. ${ }^{15}$ There is a high level of resistance to ampicillin and first-generation cephalosporin in a bacterial strain of $C$. freundii attributed to ampC gene as in our patient. ${ }^{4}$ The organisms are often sensitive to quinolones, aminoglycosides, and carbapenems. However, in our patient, Citrobacter freundii was resistant to aminoglycosides from the beginning and developed intermediate sensitivity to fluoroquinolones. The mortality rate associated with Citrobacter peritonitis is $18 \% .^{7}$ The dialysis modality was switched in $89 \%$ of surviving patients with Citrobacter peritonitis over twelve months follow up.

\section{Conclusions}

This case highlights that rare organisms like Citrobacter freundii can cause peritonitis likely due to the translocation of bacteria from the gut. There has been increased identification of peritonitis from SPICE organisms due to recent advances in microbiological techniques. Double antibiotic treatment is required for SPICE organisms as per ISPD.

\section{References}

1. Liu LH, Wang NY, Wu AY, et al. Citrobacter freundii bacteremia: Risk factors of mortality and prevalence of resistance genes. Microbiol Immunol Infect 2018;51:565-72.

2. Ranjan KP, Ranjan N. Citrobacter: An emerging health care associated urinary pathogen. Urol Ann 2013;5:313-4.

3. Janda JM, Abbott SL, Cheung WK, et al. Biochemical identification of citrobacteria in the clinical laboratory. $\mathrm{J}$ Clin Microbiol 1994;32:1850-4.

4. Kataria A, Saad E. Severe peritonitis caused by Citrobacter freundii and successful treatment with double antibiotic coverage. Indian J Nephrol 2015;25: 117.

5. Szeto CC, Chow VY, Chow KM, et al. Enterobacteriaceae peritonitis complicating peritoneal dialysis: a review of 210 consecutive cases. Kidney Int 2006;69:1245-52.

6. Brenner DJ, Grimont PA, Steigerwalt AG, et al. Classification of Citrobacter farmeri sp. nov., Citrobacter youngae sp. nov., Citrobacter sedlakii sp. nov., and three unnamed Citrobacter genospecies. Int J Syst Bacteriol 1993;
43: 645-58

7. Chao CT, Lee SY, Yang WS, et al. Citrobacter peritoneal dialysis peritonitis: rare occurrence with poor outcomes. Int J Med Sci 2013;10:1092.

8. Dervisoglu E, Yumuk Z, Yegenaga I. Citrobacter freundii peritonitis and tunnel infection in a patient on continuous ambulatory peritoneal dialysis. J Med Microbiol 2008;57:125-7.

9. Farinha A, Vaz A, Assuncao J, et al. Bactérias raras como causa de peritonite em diálise peritoneal: A experiência de um centro. Portug J Nephrol Hypertens 2013;27:187-95.

10. Kusaba T, Kirita Y, Ishida R, et al. Morphological analysis of biofilm of peritoneal dialysis catheter in refractory peritonitis patient. CEN Case Rep 2012;1:50-4.

11. Oh TR, Ma SK, Kim SW. Unusual CAPD Citrobacter freundii Peritonitis Complicated by a Fungal Infection, Identified by 16s Ribosomal RNA Gene Sequencing. Korean J Med 2015;88: 593-7.

12. Prowant B, Nolph K, Ryan L, et al. Peritonitis in continuous ambulatory peritoneal dialysis: analysis of an 8-year experience. Nephron 1986;43:105-9.

13. Singharetnam W, Holley JL. Acute treatment of constipation may lead to transmural migration of bacteria resulting in gram-negative, polymicrobial, or fungal peritonitis. Periton Dialysis Int 1996;16:423.

14. Wayne P. Clinical Laboratory Standard Institute (CLSI). Performance standards for antimicrobial susceptibility testing: Twentieth informational supplement. CLSI document M100-S20;2010.

15. Li PK, Szeto CC, Piraino B, et al. ISPD peritonitis recommendations: 2016 update on prevention and treatment. Periton Dialysis Int 2016;36:481-508. 